\title{
PENGARUH KEPUASAN KERJA DAN KOMITMEN ORGANISASI TERHADAP TURNOVER INTENTION PADA APOTEK KIMIA FARMA TANGERANG
}

\author{
${ }^{1 *}$ Desi Prasetiyani, 2 Reni Hindriari, ${ }^{3}$ San Ridwan Maulana \\ Universitas Pamulang, Tangerang Selatan, Banten, Indonesia \\ *dosen02496@unpam.ac.id
}

\begin{abstract}
Abstrak
Penelitian ini bertujuan untuk mengetahui pengaruh kepuasan kerja dan komitmen organisasi terhadap Turnover Intention pada Apotek Kimia Farma Tangerang. Metode yang digunakan adalah explanatory research dengan teknik analisis menggunakan analisis statistik dengan pengujian regresi, korelasi, determinasi dan uji hipotesis. Hasil penelitian ini kepuasan kerja berpengaruh signifikan terhadap Turnover Intention sebesar 40,1\%, uji hipotesis diperoleh nilai signifikansi (Sig.) 0,000<0,05. Komitmen organisasi berpengaruh signifikan terhadap Turnover Intention sebesar 36,7\%, uji hipotesis diperoleh nilai signifikansi (Sig.) 0,000 $<0,05$. Kepuasan kerja dan komitmen organisasi secara simultan berpengaruh signifikan terhadap Turnover Intention dengan persamaan regresi $Y=50,775-0,477 X 1$ 0,073X2 dan kontribusi pengaruh sebesar 40,2\%, uji hipotesis diperoleh nilai signifikansi (Sig.) $0,000<$ 0,05 .
\end{abstract}

Kata Kunci: Kepuasan Kerja, Komitmen Organisasi, Turnover Intention

\section{Abstract}

This study aims to determine the effect of job satisfaction and organizational commitment on Turnover Intention at Kimia Farma Pharmacy Tangerang. The method used is explanatory research with analytical techniques using statistical analysis with regression, correlation, determination and hypothesis testing. The results of this study that job satisfaction has a significant effect on Turnover Intention of $40.1 \%$, hypothesis testing obtained a significance value (Sig.) $0.000<0.05$. Organizational commitment has a significant effect on Turnover Intention by $36.7 \%$, hypothesis testing obtained a significance value (Sig.) $0.000<0.05$. Job satisfaction and organizational commitment simultaneously have a significant effect on Turnover Intention with the regression equation $Y=50.775-0.477 \mathrm{X} 1-0.073 \mathrm{X} 2$ and the contribution of the effect is $40.2 \%$, hypothesis testing obtained a significance value (Sig.) $0.000<0.05$.

Keywords: Job Satisfaction, Organizational Commitment, Turnover Intention

\section{PENDAHULUAN}

Perkembangan teknologi dan informasi yang semakin cepat serta adanya globalisasi mendorong manusia untuk berpikir semakin cerdas dan kritis. Termasuk dalam memilih layanan kesehatan. Para penyedia layanan kesehatan seperti apotek merespon perubahan tersebut dengan meningkatkan pelayanan terhadap pasien. Kepuasan pelanggan menjadi hal utama yang ingin dicapai oleh pihak rumah sakit, karena dengan terciptanya kepuasan pelanggan maka akan terbentuk loyalitas pelanggan.

Untuk dapat mencapai kepuasan pelanggan yang dalam hal ini adalah pasien, peran sumber daya manusia (SDM) menjadi faktor yang sangat menentukan. Departemen SDM berperan sangat vital dalam perusahaan karena kelangsungan hidup perusahaan sangat ditentukan oleh faktor SDM yang dimilikinya. Departemen SDM memiliki peranan strategis dalam perusahaan dan memiliki kontribusi lebih dalam menentukan perkembangan masa depan perusahaan melalui pengembangan, kreatifitas, fleksibilitas dan manajemen pro aktif. Hal ini menandakan perlu adanya pengelolaan SDM yang baik guna mencapai tujuan perusahaan, SDM harus terlibat jauh dalam mendesain rencana strategi perusahaan.

Kepuasan kerja merupakan hasil dari berbagai macam sikap (attitude) yang 
dimiliki karyawan. Adanya ketidakpuasan pada para karyawan dalam bekerja akan membawa akibat-akibat yang kurang menguntungkan baik bagi perusahaan ataupun untuk karyawan itu sendiri. Ketidakpuasan akan memunculkan dua macam perilaku yaitu penarikan diri (turnover)atau perilaku agresif sehingga menyebabkan menurunnya produktivitas.

Komitmen organisasi merupakan suatu keadaan sejauh mana seorang karyawan memihak pada suatu organisasi tertentu dan tujuannya berniat memelihara anggotanya dalam organisasi tersebut. Komitmen merupakan loyalitas dan identifikasi individu terhadap organisasi. Komitmen organisasional merupakan dimensi perilaku penting yang dapat digunakan untuk menilai kecenderungan karyawan untuk bertahan sebagai anggota organisasi, komitmen organisasional merupakan organisasi dan keterlibatan seseorang yang kuat terhadap organisasi.

Turnover didefinisikan sebagai gejala perpindahan kerja dari sebuah perusahaan. Dari definisi tersebut dapat disimpulkan bahwa yang dimaksud dengan turnover adalah keluar masuknya pekerja dari suatu organisasi secara permanen. Turnover juga dapat menunjukan ketidakstabilan karyawan. Semakin tinggi turnover, maka akan semakin sering terjadi pergantian karyawan dalam suatu perusahaan. Turnover Intention telah menjadi masalah yang serius bagi banyak perusahaan. Menurut Chen, Mei-Fang, Lin, Chieh-Peng \& Lien, Gin-Yen (2010:45) turnover intention telah menjadi isu penting selama beberapa dekade. Penulis akan melakukan survei terhadap 30 orang asisten apoteker Apotek Kimia Farma mengenai keinginan mereka untuk meninggalkan organisasi. Berdasarkan survei tersebut diketahui bahwa terdapat 7 asisten apoteker yang mencerminkan keinginan untuk berpikir keluar dari pekerjaannya (thinking of quitting). Mereka mulai berpikir untuk meninggalkan organisasi tempat mereka bekerja saat ini. Kemudian sebanyak 8 asisten apoteker mencerminkan keinginannya untuk mencari pekerjaan di tempat lain (intention to search for alternatives). Asisten apoteker tersebut sudah memiliki keinginan untuk meninggalkan pekerjaannya saat ini dan mencari pekerjaan di tempat lain. Asisten Apoteker Apotek Kimia Farma Tangerang yang mulai berpikir untuk keluar dari organisasi atau mungkin telah mendapat alternatif pekerjaan di tempat lain akan berniat untuk keluar dari organisasi tempat Ia bekerja sekarang. Terdapat 1 asisten apoteker yang mencerminkan niat untuk keluar dari organisasi, Asisten apoteker tersebut telah memiliki niat keluar dari organisasi karena memiliki alasan yang kuat atau bahkan sudah mendapat alternatif pekerjaan di tempat lain sesuai dengan keinginan maupun kebutuhannya.

Berdasarkan pra survei yang dilakukan kepada asisten apoteker Apotek Kimia Farma Tangerang, maka diketahui faktor-faktor yang diindikasikan menyebabkan turnover intention di Apotek Kimia Farma Tangerang sebagai berikut:

Tabel 1. Data Hasil Pra Survei Faktor-faktor yang Diindikasikan Menyebabkan Turnover Intention Asisten Apoteker Apotek Kimia Farma Tangerang

\begin{tabular}{|c|c|c|}
\hline Variabel & Jumlah & Persentase \\
\hline Komitmen Organisasi & 9 & $30 \%$ \\
\hline Perceived OrganizationalSupport & 3 & $10 \%$ \\
\hline Kepuasan Kerja & 14 & $47 \%$ \\
\hline Perceived Organizational Justice & 4 & $13 \%$ \\
\hline
\end{tabular}

Sumber: Apotek Kimia Farma Tangerang

Tabel di atas menunjukkan bahwa komitmen organisasi dan kepuasan kerja menjadi masalah utama yang mengindikasikan turnover intentionasisten apoteker Apotek Kimia Farma
Tangerang.Hasil pra survei menunjukkan masalah utama adalah kepuasan kerja dengan persentase $47 \%$ kemudian komitmen organisasi dengan $30 \%$.

Asisten Apoteker di Apotek Kimia 
Farma Tangerang belum memiliki kepuasan kerja yang tinggi. Berdasarkan wawancara yang dilakukan terhadap 30 asisten apoteker Apotek Kimia Farma Tangerang diketahui bahwa banyak asisten apoteker mengeluhkan naik turunnya kompensasi insentif asisten apoteker yang ditentukan dari besar kecilnya jumlah resep yang dilayani oleh asisten apoteker tersebut.Selain itu, asisten apoteker dengan masa kerja kurang dari satu tahun belum mendapatkan tunjangan insentif. Kompensasi insentif menurut Simamora dalam Kadarisman (2012:55) adalah program-program kompensasi yang mengaitkan bayaran dengan produktifitas.

Kepuasan terhadap pekerjaan asisten apoteker juga masih terbilang rendah, Sering kali setiap perputaran lokasi kerja asisten apoteker dalam satu apotek menjadi masalah. Dengan bergantinya bangsal tanggung jawab kerja asisten apoteker dalam satu apotek, maka dituntut untuk memiliki keahlian yang sedikit berbeda dan rekan yang berbeda. Hal tersebut sering menyebabkan miss antar tenaga kerja asisten apoteker, dan juga penyesuaian keterampilan yang berbeda dari setiap bangsal menyebabkan kesulitan kerja terhadap asisten apoteker. Setiap pergantian bangsal yang harus dialami oleh asisten apoteker, maka berarti berganti pula jenis penanganan terhadap pekerjaan asisten apoteker tersebut. Adaptasi dengan tanngung jawab baru dan pekerjaan asisten apoteker baru yang dituntut sangat cepat seringkali menyulitkan asisten apoteker.

Kesempatan promosi atau kenaikan gaji asisten apoteker di Apotek Kimia Farma terbilang sulit. Promosi dan kenaikan gaji ditentukan oleh penilaian kinerja asisten apoteker oleh bagian Apoteker Pengelola Apotek. Nilai asisten apoteker yang dituntut selalu tinggi

Tabel 2. Data Jumlah Asisten Apoteker Kimia Farma Tangerang

\begin{tabular}{|c|c|c|c|c|}
\hline Tahun & $\begin{array}{c}\text { Jumlah Asisten } \\
\text { Apoteker }\end{array}$ & $\begin{array}{c}\text { Jumlah } \\
\text { Asisten Apoteker } \\
\text { Masuk }\end{array}$ & $\begin{array}{c}\text { Jumlah } \\
\text { Asisten Apoteker } \\
\text { Keluar }\end{array}$ & $\begin{array}{c}\text { Persentase } \\
\text { Turnover }\end{array}$ \\
\hline 2015 & 179 & 11 & 11 & $6.14 \%$ \\
2016 & 179 & 63 & 26 & $14.52 \%$ \\
2017 & 216 & 34 & 24 & $11.11 \%$ \\
\hline
\end{tabular}

menyebabkan promosi dan kenaikan gaji menjadi lebih sulit untuk tercapai. Kenaikan gaji ditentukan oleh sistem poin.Poin tersebut hanya bisa didapatkan asisten apoteker berdasarkan kriteria kinerja yang telah ditentukan oleh Apotek Kimia Farma Tangerang. Tingginya kriteria point tersebut membuat setiap asisten apoteker Apotek Kimia Farma Tangerang harus bekerja lebih keras untuk mendapatkan poin yang nantinya menjadi kriteria kenaikan gajinya

Masalah yang terdapat dalam apotek tersebut berdasarkan pengamatan awal dari peneliti adalah komitmen organisasi. Asisten Apoteker Apotek Kimia Farma Tanggerang belum memiliki komitmen organisasi yang tinggi. Apoteker selaku bagian yang mengurus tenaga kerja asisten apoteker Apotek Kimia Farma Tangerang mengatakan bahwa banyak dari tenaga kerja asisten apoteker yang memiliki rasa pengabdian yang rendah, dapat dilihat dari rendahnya rasa keterikatan dinilai melalui pengorbanan pribadi asisten apoteker untuk kebaikan Apotek Kimia Farma Tanggerang. Hal tersebut mengindikasikan rendahnya organizational loyalty dari asisten apoteker.

Berdasarkan wawancara dengan General Manager Apotek Kimia Farma Tangerang, diketahui bahwa banyak dari asisten apoteker Apotek Kimia Farma Tangerang kurang mempunyai kepedulian terhadap pekerjaannya dan memiliki keterlibatan kerja yang rendah. Selain itu asisten apoteker juga kurang dilibatkan dalam pengambilan keputusan organisasi. Hal-hal di atas menyebabkan munculnya turnover intention pada Apotek Kimia Farma Tangerang yang nantinya dapat berdampak pada tinggi rendahnya turnover pada apotek tersebut. 


\begin{tabular}{|l|l|l|l|l|}
\hline 2018 & 226 & 28 & 38 & $16.81 \%$ \\
2019 & 216 & 4 & 32 & $14.28 \%$ \\
\hline 2020 & 188 & & \\
\hline \multicolumn{4}{|c|}{ Persentase rata-rata turnover } \\
\hline
\end{tabular}

Sumber: Data HRD Apotek Kimia Farma Tangerang

Berdasarkan data jumlah karyawan Apotek Kimia FarmaTangerang lima tahun terakhir, nampak bahwa tingkat turnover dari tahun 2015-2020 mengalami perubahan persentase setiap tahunnya. Dimana dari tabel tersebut menunjukkan setelah tahun 2015, persentase turnover selalu melebihi $10 \%$, dengan persentase rata-rata tingkat turnover dari tahun 2015-2018 sebesar 12.57\%. Data tersebut mengindikasikan adanya permasalahan di dalam manajemen Apotek Kimia Farma Tanggerang. Turnover asisten apoteker pada Apotek Kimia Farma Tanggerang tidak terjadi begitu saja, namun hal tersebut tercipta karena adanya keinginan untuk keluar (turnover intention) dari asisten apoteker Apotek Kimia Farma Tangerang tersebut.

Berdasarkan fenomena di atas peneliti menganggap perlu untuk melakukan penelitian lebih lanjut mengenai pengaruh antar variabel kepuasan kerja, komitmen organisasi, dan turnover intention pada asisten apoteker Apotek Kimia Farma Tangerang dengan judul: "Pengaruh Kepuasan Kerja dan Komitmen Organisasi terhadap Turnover Intention Karyawan Apotek Kimia Farma Tangerang".

\section{TINJAUAN PUSTAKA}

\section{Kepuasan Kerja}

Yang dimaksud dengan Kepuasan Kerja terhadap Turn Over Intention adalah bentuk kepuasan kerja yang diperoleh asisten apoteker pada Apotek Kimia Farma Tangerang yang dapat mengidentifikasi keinginan untuk berhenti dari perusahaan (Turn Over Intention). Menurut Kreitner dan Kinichi (2010) mendefinisikan kepuasan kerja sebagai respon perasaan atau emosional terhadap pekerjaan seseorang.

\section{Komitmen Organisasi}

Yang dimaksud dengan Komitmen Organisasi dalam penelitian ini adalah sikap yang ditunjukkan oleh Asisten Apoteker dalam melakukan pekerjaan pada Apotek Kimia Farma Tangerang. Menurut Alwi dalam Nanda dkk (2013), mendefinisikan Komitmen organisasi adalah sikap karyawan untuk tetap berada dalam organisasi dan terlibat dalam upaya-upaya mencapai misi, nilai-nilai dan tujuan organisasi.

\section{Turnover Intention}

Yang dimaksud dengan Turn over Intention dalam penelitian ini adalah keinginan karyawan untuk berhenti dari perusahaan atau keinginan karyawan untuk mencari pekerjaan lain dalam hal ini Asisten Apoteker Kimia Farma Tangerang. Menurut Lee dalam Varshney (2014) menyatakan bahwa turnover intention adalah persepsi subjektif dari anggota organisasi untuk keluar dari pekerjaan saat ini untuk kesempatan lain.

\section{METODE}

Populasi dalam penelitian ini berjumlah 65 responden Apotek Kimia Farma Tangerang. Sampel dalam penelitian ini berjumlah 65 responden. Jenis penelitian yang dipakai adalah kuantitatif, dimana tujuannya adalah untuk mengetahui pengaruh antara variabel bebas terhadap variabel terikat baik parsial maupun simultan Dalam menganalisis data digunakan uji instrumen, uji asumsi klasik, regresi, koefisien korelasi, koefisien determinasi dan uji hipotesis.

\section{HASIL DAN PEMBAHASAN}

\section{Analisis Deskriptif}

Pada pengujian ini digunakan untuk mengetahui skor minimum dan maksimum, mean score dan standar deviasi dari masing-masing variabel. Adapun hasilnya sebagai berikut:

Tabel 3. Hasil Analisis Descriptive Statistics 


\begin{tabular}{lr|r|r|r|r}
\multicolumn{7}{c}{ Descriptive Statistics } \\
& N & Minimum & Maximum & Mean & Std. Deviation \\
\hline Kepuasan Kerja (X1) & 65 & 16 & 49 & 34.97 & 7.838 \\
\hline Komitmen Organisasi (X2) & 65 & 18 & 50 & 35.29 & 8.459 \\
\hline Turnover Intention (Y) & 65 & 17 & 46 & 31.52 & 6.817 \\
\hline Valid N (listwise) & 65 & & & & \\
\hline
\end{tabular}

Kepuasan kerja diperoleh varians minimum sebesar 16 dan varians maximum 49 dengan mean score sebesar 34,97 dengan standar deviasi 7,838.

Komitmen organisasi diperoleh varians minimum sebesar 18 dan varians maximum 50 dengan mean score sebesar 35,29 dengan standar deviasi 8,459.

Turnover Intention diperoleh varians minimum sebesar 17 dan varians maximum 46 dengan mean score sebesar 31,52 dengan standar deviasi 6,817.

\section{Analisis Kuantitatif.}

Pada analisis ini dimaksudkan untuk mengetahui pengaruh variabel independen terhadap variabel dependen. Adapun hasil pengujian sebagai berikut:

\section{a. Analisis Regresi Linier Berganda}

Uji regresi ini dimaksudkan untuk mengetahui perubahan variabel dependen jika variabel independen mengalami perubahan. Adapun hasil pengujiannya sebagai berikut:

Tabel 4. Hasil Pengujian Regresi Linier Berganda

Coefficients $^{a}$

\begin{tabular}{|c|c|c|c|c|c|}
\hline \multirow[b]{3}{*}{ Model } & \multicolumn{2}{|c|}{ Coefficients $^{\mathrm{a}}$} & \multirow{3}{*}{$\begin{array}{l}\text { Standardized } \\
\text { Coefficients } \\
\text { Beta }\end{array}$} & \multirow[b]{3}{*}{$\mathrm{t}$} & \multirow[b]{3}{*}{ Sig. } \\
\hline & Unstandard & d Coefficients & & & \\
\hline & B & Std. Error & & & \\
\hline 1 (Constant) & 50.775 & 3.060 & & 16.594 & .000 \\
\hline Kepuasan Kerja (X1) & -.477 & .249 & -.548 & -1.916 & .060 \\
\hline Komitmen Organisasi (X2) & -.073 & .231 & -.091 & -.317 & .752 \\
\hline
\end{tabular}

a. Dependent Variable: Turnover Intention $(\mathrm{Y})$

Berdasarkan hasil pengujian pada tabel di atas, diperoleh persamaan regresi $\mathrm{Y}=50,775$ 0,477X1 - 0,073X2. Dari persamaan tersebut dijelaskan sebagai berikut:

1) Konstanta sebesar 50,775 diartikan jika kepuasan kerja dan komitmen organisasi tidak ada, maka telah terdapat nilai Turnover Intention sebesar 50,775 point.

2) Koefisien regresi kepuasan kerja sebesar -0,477, angka ini negatif artinya setiap ada penurunan kepuasan kerja sebesar -0,477 maka Turnover Intention akan mengalami peningkatan sebesar $-0,477$ point, atau jika kepuasan kerja menurun maka turnover meningkat.
3) Koefisien regresi komitmen organisasi sebesar $-0,073$, angka ini negatif artinya setiap ada penurunan komitmen organisasi sebesar -0,073 maka Turnover Intention akan mengalami peningkatan sebesar $-0,073$ point, atau jika komitmen organisasi menurun maka turnover meningkat.

\section{b. Analisis Koefisien Korelasi}

Analisis koefisien korelasi dimaksudkan untuk mengetahui tingkt kekuatan hubungan dari variabel independen terhadap variabel dependen baik secara parsial maupun simultan. Adapun hasil pengujian sebagai berikut: 
Tabel 5. Hasil Pengujian Koefisien Korelasi Kepuasan kerja Terhadap Turnover Intention.

\section{Correlations $^{b}$}

Kepuasan Kerja (X1) Turnover Intention (Y)

\begin{tabular}{l|lr|r}
\hline Kepuasan Kerja (X1) & Pearson Correlation & 1 & $-.633^{\star *}$ \\
\cline { 2 - 4 } & Sig. (2-tailed) & -.600 \\
\hline Turnover Intention (Y) & Pearson Correlation & .000 & 1 \\
\cline { 2 - 4 } & Sig. (2-tailed) & & \\
\hline
\end{tabular}

**. Correlation is significant at the 0.01 level (2-tailed).

b. Listwise $\mathrm{N}=65$

Berdasarkan hasil pengujian diperoleh nilai korelasi sebesar - 0,633 artinya kepuasan kerja memiliki Tabel 6. Hasil Pengujian Koefisien Korelasi Komitmen organisasi Terhadap Turnover Intention. Correlations $^{\mathrm{b}}$ hubungan yang negatif kuat terhadap Turnover Intention.

\begin{tabular}{llr|r} 
& \multicolumn{1}{c}{ Correlations $^{\mathbf{b}}$} & $\begin{array}{c}\text { Komitmen } \\
\text { Organisasi (X2) }\end{array}$ & \multicolumn{1}{c}{$\begin{array}{c}\text { Turnover } \\
\text { Intention (Y) }\end{array}$} \\
\hline Komitmen Organisasi (X2) & Pearson Correlation & 1 & $-.606^{* *}$ \\
\cline { 2 - 4 } & Sig. (2-tailed) & & .000 \\
\hline Turnover Intention (Y) & Pearson Correlation & $-.606^{* *}$ & 1 \\
\cline { 2 - 4 } & Sig. (2-tailed) & .000 & \\
\hline
\end{tabular}

**. Correlation is significant at the 0.01 level (2-tailed).

b. Listwise $\mathrm{N}=65$

Berdasarkan hasil pengujian hubungan yang negatif kuat terhadap diperoleh nilai korelasi sebesar $-0,606$ Turnover Intention. artinya komitmen organisasi memiliki

Tabel 7. Hasil Pengujian Koefisien Korelasi Kepuasan kerja dan Komitmen organisasi secara simultan Terhadap Turnover Intention.

Model Summaryb

\begin{tabular}{|c|c|c|c|c|}
\hline \multicolumn{5}{|c|}{ Model Summaryb } \\
\hline Model & $\mathrm{R}$ & R Square & $\begin{array}{l}\text { Adjusted R } \\
\text { Square }\end{array}$ & $\begin{array}{l}\text { Std. Error of the } \\
\text { Estimate }\end{array}$ \\
\hline 1 & $.634^{\mathrm{a}}$ & .402 & .383 & 5.355 \\
\hline
\end{tabular}

a. Predictors: (Constant), Komitmen Organisasi (X2), Kepuasan Kerja (X1)

b. Dependent Variable: Turnover Intention $(\mathrm{Y})$

Berdasarkan hasil pengujian diperoleh nilai korelasi sebesar 0,634 artinya kepuasan kerja dan komitmen organisasi secara simultan memiliki hubungan yang kuat terhadap Turnover Intention.

\section{c. Analisis Koefisien Determinasi}

Analisis koefisien determinasi dimaksudkan untuk mengetahui besarnya persentase pengaruh dari variabel independen terhadap variabel dependen baik secara parsial maupun simultan. Adapun hasil pengujian sebagai berikut:

Tabel 8. Hasil Pengujian Koefisien Determinasi Kepuasan kerja Terhadap Turnover Intention.

\section{Model Summary}

\begin{tabular}{lr|r|r|rr} 
Model & $\mathrm{R}$ & \multicolumn{2}{c|}{$\begin{array}{c}\text { Adjusted R } \\
\text { Square }\end{array}$} & \multicolumn{2}{c}{$\begin{array}{c}\text { Std. Error of the } \\
\text { Estimate }\end{array}$} \\
\hline 1 & $.633^{\mathrm{a}}$ & .401 & .392 & 5.317 \\
\hline
\end{tabular}

a. Predictors: (Constant), Kepuasan Kerja (X1)

Berdasarkan hasil pengujian diperoleh nilai determinasi sebesar
0,401 artinya kepuasan kerja memiliki kontribusi pengaruh sebesar $40,1 \%$ 
terhadap Turnover Intention.

Tabel 9. Hasil Pengujian Koefisien Determinasi Komitmen organisasi Terhadap Turnover Intention.

\section{Model Summary}

\begin{tabular}{l|c|c|cr} 
Model & $\mathrm{R}$ & R Square & $\begin{array}{c}\text { Adjusted R } \\
\text { Square }\end{array}$ & \multicolumn{2}{c}{$\begin{array}{c}\text { Std. Error of the } \\
\text { Estimate }\end{array}$} \\
\hline 1 & $.606^{\mathrm{a}}$ & .367 & .357 & 5.468 \\
\hline a. Predictors: (Constant), Komitmen Organisasi (X2) & & &
\end{tabular}

Berdasarkan hasil pengujian diperoleh nilai determinasi sebesar memiliki kontribusi pengaruh sebesar 0,367 artinya komitmen organisasi $36,7 \%$ terhadap Turnover Intention.

Tabel 10. Hasil Pengujian Koefisien Determinasi Kepuasan kerja dan Komitmen organisasi Terhadap Turnover Intention.

\begin{tabular}{|c|c|c|c|c|}
\hline \multicolumn{5}{|c|}{ Model Summary } \\
\hline Model & $\mathrm{R}$ & R Square & $\begin{array}{l}\text { Adjusted R } \\
\text { Square }\end{array}$ & $\begin{array}{l}\text { Std. Error of the } \\
\text { Estimate }\end{array}$ \\
\hline 1 & $.634^{a}$ & .402 & .383 & 5.355 \\
\hline
\end{tabular}

a. Predictors: (Constant), Komitmen Organisasi (X2), Kepuasan Kerja (X1)

b. Dependent Variable: Turnover Intention $(\mathrm{Y})$

Berdasarkan hasil pengujian diperoleh nilai determinasi sebesar 0,402 artinya kepuasan kerja dan komitmen organisasi secara simultan memiliki kontribusi pengaruh sebesar 40,2\% terhadap Turnover Intention, sedangkan sisanya sebesar $59,8 \%$ dipengaruhi faktor lain.

\section{d. Uji Hipotesis}

Uji hipotesis Parsial (Uji t)

Pengujian hipotesis dengan uji $t$ digunakan untuk mengetahui hipotesis parsial mana yang diterima.

Hipotesis pertama: Terdapat pengaruh yang negatif signifikan antara kepuasan kerja terhadap Turnover Intention.

Tabel 11. Hasil Uji Hipotesis Kepuasan kerja Terhadap Turnover Intention.

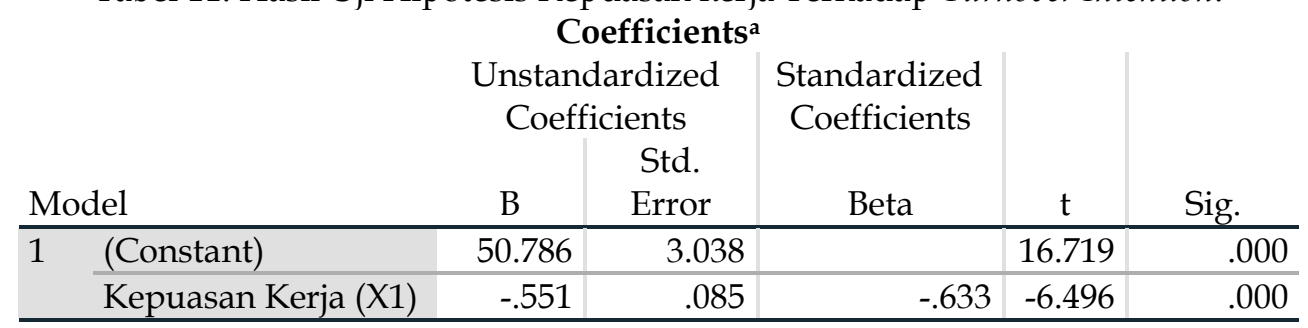

a. Dependent Variable: Turnover Intention $(\mathrm{Y})$

Berdasarkan hasil pengujian pada tabel di atas, diperoleh nilai signifikansi (Sig.) $0,000<0,05$, dengan demikian hipotesis pertama yang diajukan bahwa terdapat pengaruh yang negatif signifikan atara Tabel 12. Hasil Uji Hipotesis Komitmen organisasi Terhadap Turnover Intention.

\section{Coefficients ${ }^{\mathrm{a}}$}

Unstandardized

Coefficients kepuasan kerja terhadap Turnover Intention diterima.

Hipotesis kedua: Terdapat pengaruh yang negatif signifikan antara komitmen organisasi terhadap Turnover Intention.

\begin{tabular}{lc|c|c|c|c} 
& \multicolumn{2}{c}{$\begin{array}{c}\text { Unstandardized } \\
\text { Coefficients }\end{array}$} & $\begin{array}{c}\text { Standardized } \\
\text { Coefficients }\end{array}$ & & \\
Model & $\mathrm{B}$ & $\begin{array}{c}\text { Std. } \\
\text { Error }\end{array}$ & Beta & $\mathrm{t}$ & Sig. \\
\hline 1 (Constant) & 48.747 & 2.931 & & 16.631 & .000 \\
\hline
\end{tabular}




\begin{tabular}{l|l|l|l|l|l}
\hline $\begin{array}{l}\text { Komitmen Organisasi } \\
(\mathrm{X} 2)\end{array}$ & -.488 & .081 & -.606 & -6.040 & .000 \\
\hline
\end{tabular}

a. Dependent Variable: Turnover Intention (Y)

Berdasarkan hasil pengujian pada tabel di atas, diperoleh nilai signifikansi (Sig.) 0,000 < 0,05, dengan demikian hipotesis kedua yang diajukan bahwa terdapat pengaruh yang negatif signifikan atara komitmen organisasi terhadap Turnover Intention diterima.

\section{Uji Hipotesis Simultan (Uji F)}

Pengujian hipotesis dengan uji $\mathrm{F}$ digunakan untuk mengetahui hipotesis simultan yang mana yang diterima.

Hipotesis ketiga Terdapat pengaruh yang signifikan antara kepuasan kerja dan komitmen organisasi terhadap Turnover Intention.

Tabel 13. Hasil Uji Hipotesis Kepuasan kerja dan Komitmen organisasi Terhadap Turnover Intention.

\section{ANOVA $^{\mathrm{a}}$}

\begin{tabular}{|c|c|c|c|c|c|c|}
\hline \multirow{2}{*}{\multicolumn{2}{|c|}{ Model }} & \multicolumn{2}{|c|}{ 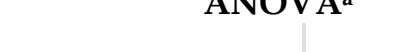 } & \multirow[b]{2}{*}{$\begin{array}{l}\text { Mean } \\
\text { Square }\end{array}$} & \multirow[b]{2}{*}{$\mathrm{F}$} & \multirow{3}{*}{$\frac{\text { Sig. }}{.000^{\mathrm{b}}}$} \\
\hline & & Sum of Squares & $\mathrm{df}$ & & & \\
\hline \multirow[t]{3}{*}{1} & Regression & 1196.023 & 2 & 598.012 & 20.851 & \\
\hline & Residual & 1778.192 & 62 & 28.681 & & \\
\hline & Total & 2974.215 & 64 & & & \\
\hline
\end{tabular}

a. Dependent Variable: Turnover Intention $(\mathrm{Y})$

b. Predictors: (Constant), Komitmen Organisasi (X2), Kepuasan Kerja (X1)

Berdasarkan hasil pengujian pada tabel di atas, diperoleh nilai signifikansi (Sig.) $0,000<0,05$, dengan demikian hipotesis ketiga yang diajukan bahwa terdapat pengaruh yang signifikan atara kepuasan kerja dan komitmen organisasi terhadap Turnover Intention diterima.

\section{PEMBAHASAN HASIL PENELITIAN}

1. Pengaruh Kepuasan kerja Terhadap Turnover Intention

Kepuasan kerja berpengaruh negatif signifikan terhadap Turnover Intention dengan korelasi sebesar $-0,633$ atau memiliki hubungan yang kuat dengan kontribusi pengaruh sebesar 40,1\%. Pengujian hipotesis diperoleh nilai signifikansi (Sig.) 0,000 < 0,05. Dengan demikian hipotesis pertama yang diajukan bahwa terdapat berpengaruh yang negatif signifikan antara kepuasan kerja terhadap Turnover Intention diterima.

\section{Pengaruh Komitmen Organisasi Terhadap Turnover Intention}

Komitmen organisasi berpengaruh negatif signifikan terhadap Turnover Intention dengan korelasi sebesar -0,606 atau memiliki hubungan yang kuat dengan kontribusi pengaruh sebesar $36,7 \%$. Pengujian hipotesis diperoleh nilai signifikansi (Sig.) 0,000 $<0,05$. Dengan demikian hipotesis kedua yang diajukan bahwa terdapat berpengaruh yang negatif signifikan antara komitmen organisasi terhadap Turnover Intention diterima.

\section{Pengaruh Kepuasan kerja dan Komitmen organisasi Terhadap Turnover Intention}

Kepuasan kerja dan komitmen organisasi berpengaruh signifikan terhadap Turnover Intention dengan diperoleh persamaan regresi $Y=50,775$ 0,477X1 - 0,073X2, nilai korelasi sebesar 0,634 atau memiliki hubungan yang kuat dengan kontribusi pengaruh sebesar $40,2 \%$ sedangkan sisanya sebesar 59,8\% dipengaruhi faktor lain. Pengujian hipotesis diperoleh signifikansi (Sig.) $0,000<0,05$. Dengan demikian hipotesis ketiga yang diajukan bahwa terdapat berpengaruh signifikan antara kepuasan 
kerja dan komitmen organisasi terhadap Turnover Intention diterima.

\section{PENUTUP}

\section{Kesimpulan}

1. Kepuasan kerja berpengaruh negatif signifikan terhadap Turnover Intention dengan kontribusi pengaruh sebesar 40,1\%. Uji hipotesis diperoleh nilai signifikansi (Sig.) 0,000 <0,05.

2. Komitmen organisasi berpengaruh negatif signifikan terhadap Turnover Intention dengan kontribusi pengaruh sebesar 36,7\%. Uji hipotesis diperoleh nilai signifikansi (Sig.) 0,000 $<0,05$.

3. Kepuasan kerja dan komitmen organisasi berpengaruh signifikan terhadap Turnover Intention dengan kontribusi pengaruh sebesar 40,2\% sedangkan sisanya sebesar 59,8\% dipengaruhi faktor lain. Uji hipotesis diperoleh nilai signifikansi (Sig.) 0,000 < 0,05 .

\section{Saran}

1. Variabel Kepuasan kerja, pernyataan yang paling lemah adalah gaji yang saya terima dari perusahaan dapat

A.A Anwar Prabu Mangkunegara, "Manajemen Sumber Daya Manusia". Gramedia, Jakarta Selatan, 2014.

Ahmed, N., Rasheed, A., and Jehanzeb, K. (2013). An Exploration of Predictors of. Organizational Citizenship Behaviour and Its Significant

Amirullah, "Pengantar Manajemen", Mitra Wacana Media, Jakarta, 2015

Bernardin, H. John dan Joyce E.A. Russell, "Human Resource Management", An Experiential Approach, McGrow Hill, Singapore, 2013.

Chen, Mei-Fang, Lin, Chieh-Peng.,\& Lien, Gin-Yen. (2010). Modeling Job Stress as a Mediating Role in Predicting Turnover Intention. The Service Industries Journal. Vol 31. Num. 8. pp 1743-9507

Dessler, Gerry, "Human Resources Management", Prenticehall, International Inc, London, 2014. mencukupi kehidupan saya, dimana hanya mencapai score sebesar 3,25. Untuk lebih baik lagi perusahaan harus mempertimbangkan kenaikan gaji agar mampu mencukupi kebutuhan karyawan.

2. Variabel Komitmen Organisasi, pernyataan yang paling lemah adalah karyawan sulit meninggalkan perusahaan ini karena takut tidak mendapatkan kesempatan kerja ditempat lain, dimana hanya mencapai score sebesar 3,35. Untuk lebih baik lagi perusahaan harus memberikan penguatan dan kanyamanan dalam bekerja sehingga karyawan merasa betah kerja di perusahaan

3. Variabel Turnover Intention, pernyataan yang paling lemah adalah karyawan berniat untuk tetap dalam posisi sekarang sambil menunggu keputusan dari perusahaan lain, dimana hanya mencapai score sebesar 2,97. Untuk lebih baik lagi perusahaan harus mendorong terciptanya karyawan yang loyal terhadap perusahaan

\section{DAFTAR PUSTAKA}

Insani, P. B. E. B. (2020). Hubungan Gaya Kepemimpinan Dengan Produktivitas Kerja Pegawai Bmt El Bina Insani Cugenang. Jurnal Agrita Vol, 2(1).

Istijianto, "Aplikasi Praktis Riset Pemasaran", Gramedia Pustaka Utama, Jakarta, 2012.

Jonathan Sarwono, "Metode Penelitian Kuantitatif Dan Kualitatif", Graha Ilmu, Yogyakarta, 2012

Juniarari. (2011). Komitmen Organisasi. Jakarta

Kasmir, :Manajemen Sumber Daya Manusia(Teori dan Praktek), Jakarta: PT. Raja Grafindo, 2016

Kreitner, Kinicki. 2010. Organizational Behavior. New York: McGraw-Hill

Kristianti, L. S., et al. (2021). Pengaruh Motivasi Dan Disiplin Kerja Terhadap Kinerja Pegawai Pada Dinas Pariwisata Purwakarta. Jurnal Ilmiah PERKUSI, 1(1), 101-109. 
Luthans, Fred, “Organizational Behavior:, McGraw-Hill, New York, 2012.

Mathis, Robert. L \& Jackson John.H, "Manajemen Sumber Daya Manusia" Jilid 1, Salemba Empat, Jakarta, 2014.

Michael R Carrell, "Human Resourcee Managemen Global for managing Diverse Wokplace", Edition, Prenice Hall Inc. Nre Jersey, 2015.

Miftah Thoha "Kepemimpinan Dalam Manajemen", Edisi Pertama, PT. Raja Grafindo, Jakarta, 2012.

Mobley,W. H. 2011. Pergantian Karyawan: Sebab, Akibat dan Pengendaliannya. Alih Bahasa : Nurul Imam. Jakarta: PT Pustaka Binaman Pressindo

Nurjaya, N., et al. (2021). The Effect of Product Promotion and Innovation Activities on Marketing Performance in Middle Small Micro Enterprises in Cianjur. Budapest International Research and Critics Institute (BIRCIJournal): Humanities and Social Sciences, $4(1), 528-540$.

(2021). Pengaruh Kompetensi

Sumber Daya Manusia Dan Kemampuan Pemanfaatan Teknologi Terhadap Kinerja Aparatur Desa Pada Kantor Kepala Desa Di Kabupaten Gunungkidul, Yogyakarta. JENIUS (Jurnal Ilmiah Manajemen Sumber Daya Manusia), 4(3), 332-346.

(2020). The Effect of Work Stress and Work Conflict on
Employees Turnover Intention In Middle Small Micro Enterprises (MSMEs) In South Tangerang Region. International Journal of Educational Administration, Management, and Leadership , 51-62.

Paramarta, V., Dewi, R. R. V. K., Rahmanita, F., Hidayati, S., \& Sunarsi, D. (2021). Halal Tourism in Indonesia: Regional Regulation and Indonesian Ulama Council Perspective. International Journal of Criminology and Sociology, 10, 497-505.

Prasada, D., Sunarsi, D., \& Teriyan, A. (2020). Pengaruh Etos Kerja Dan Kompensasi Terhadap Komitmen Organisasi Pada DHL Logistic Di Jakarta. JENIUS (Jurnal Ilmiah Manajemen Sumber Daya Manusia), $4(1), 51-60$.

Rekha, Sree., \& Kamalanabhan. (2012). A Study on The Employee Turnover Intention In ITES/BPO Sector.

Suryani, N. L., Sularmi, L., Eka, P. D., Sunarsi, D., \& Maddinsyah, A. (2020). The Analysis of Career Development and Placement of Employee Performance in Pt. Global Means of Transindo in Jakarta. Solid State Technology, 63(6), 1382-1389.

W.F. Cascio dalam Robbins, "Managing Human resources productivity of Work", Edisi ketujuh, terjemahan, Jakarta, 2012. 